\title{
IMPLEMENTATION AND SUPERVISION OF OFFICIAL DISCRETION IN LOCAL GOVERNMENT OF REPUBLIC OF INDONESIA
}

\author{
Nurfaika Ishak \\ Faculty of Law, University of Indonesia \\ nurfaika.ishak@ui.ac.id
}

\begin{abstract}
Discretion is particularly vulnerable to the misuse of authority by officials which could lead to collusion, corruption and nepotism and made the administration of government no longer aims for public's benefit and interest but for the advantage of a few and conflict interest of corrupt people. Therefore, the clear procedures related to the implementation for supervision of the discretion, especially on local government in the the Republic of Indonesia. This study aims to provide a more in depth understanding of the issues of implementation and supervision of discretion of government officials. The form of legal research used in this study is juridical-normative research. Juridical-normative legal research consists of research on principles, systematics, and legal synchronization. This study also based on laws and regulations related to the implementation and supervision of discretion by officials. This study shows that every official of the state administration in performing their duties shall be based on legitimate authority, which is provided by laws and regulations. Governance should be based on law (wet matigheid van bestuur=legality principle $=$ le rincile de la egalite de'l administration). The supervision of the discretion of government officials is prohibited to the abuse of authority. Government Officials are prohibited from misusing authority. Supervision is carried out by internal control apparatus. The results of supervision are: no errors; there are administrative errors; or there are administrative errors with a financial loss to the state.
\end{abstract}

\section{Keywords:}

Discretion; Supervision; Local Government

\begin{abstract}
Abstrak
Diskresi merupakan wewenang yang sangat rentan disalahgunakan oleh pejabat yang dapat menyebabkan kolusi, korupsi dan nepotisme serta mengakibatkan administrasi pemerintahan tidak lagi bertujuan untuk kepentingan publik, tetapi untuk keuntungan segelintir orang dan konflik kepentingan bagi orang-orang yang korup. Oleh karena itu, prosedur yang jelas terkait dengan pelaksanaan untuk
\end{abstract}


pengawasan diskresi sangat diperlukan, terutama pada pemerintah daerah di Republik Indonesia. Penelitian ini bertujuan untuk memberikan pemahaman yang lebih mendalam tentang masalah pelaksanaan dan pengawasan diskresi pejabat pemerintah. Bentuk penelitian hukum yang digunakan dalam penelitian ini adalah penelitian yuridis normatif. Penelitian hukum yuridis-normatif terdiri dari penelitian tentang prinsip, sistematika, dan sinkronisasi hukum. Studi ini juga didasarkan pada hukum dan peraturan yang terkait dengan implementasi dan pengawasan kebijakan oleh pejabat. Studi ini menunjukkan bahwa setiap pejabat administrasi negara dalam menjalankan tugasnya harus berdasarkan pada otoritas yang sah, yang disediakan oleh undang-undang dan peraturan. Tata kelola harus didasarkan pada hukum (wet matigheid van bestuur=legality principle=le rincile de la egalite de'l administration). Pengawasan atas kebijakan pejabat pemerintah dilarang untuk penyalahgunaan wewenang. Pejabat Pemerintah dilarang menyalahgunakan wewenang. Pengawasan dilakukan oleh peralatan kontrol internal. Hasil pengawasan adalah: tidak ada kesalahan; ada kesalahan administrasi; atau ada kesalahan administrasi dengan kerugian keuangan kepada negara.

Kata Kunci:

Diskresi; Pengawasan; Pemerintah Daerah

\section{A. INTRODUCTION}

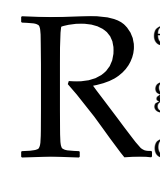

epublic of Indonesia is a unitary state consists of several provinces and local governments that arrange the government by adopting the principle of decentralization. The principle of decentralization is a principle which gives flexibility to the local government officials to manage, arrange and carry out their respective regional autonomy within the Framework of the Unitary State of the Republic of Indonesia. Article 18 of Indonesian Constitution 1945 provides a clear legal standing for local regions officials to implement their autonomy by their affairs, except for government affairs which by law are determined as central government affairs.

In the context of regional autonomy by the principle of decentralization is a manifestation from the principle of autonomy which is comprehensive, real and to be responsible. Normatively, definition of the principle of decentralization can be seen in Article 1 point (8) of Law number 23 of 2014 on Regional Government of Indonesia, it said that: "Decentralization is the delivery of government authority by the government to the autonomous regions to regulate and manage government affairs within the system of the Republic of Indonesia Republic".

In carrying out the autonomy of local government, local officials will usually find issues that do not have rules, or do not have complete rules on a concrete issue 
related to the implementation of local government. These conditions made local government officials having the authority to take decisions and/or actions that can solve the issue above, known as discretion.

Discretion is a decision and/or action determined and/or performed by a government official to address the concrete concerns faced in governing governance in terms of choice, non-regulating, incomplete or unclear legislation and/or government stagnation ${ }^{1}$. A government official has the authority to take a decision that is not/has not been regulated in writing in the legislation to solve a problem faced. Good officials cannot argue to refuse to settle a case on the grounds that there is no law governing it, especially if the problem has a very big impact to the public and administration.

Discretion in the Black Law Dictionary, means "A public official's power or right to act in certain circumstances according to personal judgment and conscience". Discretion is defined as one of the means by which the state or state administrative bodies may move to act without the full discretion of the law, or the action undertaken by prioritizing the achievement of the objective (doelmatigheid) rather than in accordance with applicable law (rechmatigheid) ${ }^{2}$. Officials or state administrative bodies may engage in acts not yet/not regulated in a detailed legislation, with the record of such acts having the aim of administering the good governance.

Article 23 of Law no. 30 of 2014 on Government Administration, grouping the discretion of government officials such as:

a) decision-making and/or action under the provisions of laws and regulations which provide an option Decision and / or Action;

b) decision-making and/or action because the laws and regulations are not regulated;

c) decision-making and/or action due to incomplete or unclear legislation; and

d) decision-making and/or action due to government stagnation for broader interests.

However, the implementation of discretion is vulnerable to the abuse of power (detournement de pouvoir) and arbitrariness (willekeur), in the absence of written rules that underlie the official in deciding a case categorized in the discretion. As the adagium of Lord Acton, "Power tends to corrupt and absolute power corrupt absolutely". Thats why the Law No. 30 of 2014 on Government Administration in Article 22 paragraph (2) limits the purpose of using government officials' discretion only to expedite the administration of the government, to fill the legal void; provide legal certainty; and overcome the stagnation of government in certain circumstances for the benefit and the public interest.

\footnotetext{
${ }^{1}$ Republic of Indonesia Law, Article 1 Number 30 of 2014 tentang Administrasi Pemerintahan

${ }^{2}$ Ridwan HR, Dimensi Hukum Administrasi dan Peradilan Administrasi, (Yogyakarta: FH UII, 2009), p.73
} 
The use of discretion is a particularly vulnerable to the misuse of authority by officials who can generate collusion, corruption and nepotism and result in the administration of government no longer aims for the public interest but for the interest of a few. So, the importance of clear procedures related to the implementation and the correct mechanism for supervision of the implementation of the discretion, especially on the implementation of local government within the Unitary State of the Republic of Indonesia is necessary. This research aims to provide a more in-depth understanding of the issues of implementation of decisions and / or actions of officials (discretion) and its supervision. This research also will be described about legal consequences of discretion by officials of local government related with laws and regulations.

\section{B. METHODOLOGY}

1. Form of Research

The form of research used in this study was juridical-normative (doctrinal) research which literature study was become the main issue in this research. Juridical-normative legal research consists of research on principles, systematic, legal synchronization and law comparative. This research also conducted on all laws and regulations related to the implementation and supervision of officials discretion in the implementation of good government.

2. Typology of Research

This research was descriptive and explanatory, which describe about a symptom on the use of discretion by government officials in local governance and explain it with related concepts.

3. Data Type

Data used in this research were: secondary data which obtained from literature study.

Type of Legal Material:

a. Primary Legal Material

Primary legal materials were laws and regulations from legislation which relates to the issues.

b. Secondary Legal Material

Secondary legal materials were scientific papers, scientific journals and other literature related with the issues.

c. Tertiary Legal Material

Tertiary legal materials were materials derived from sources such as legal dictionaries and others related with the. the implementation and supervision of officials' discretion in the government.

C. RESULT AND DISCUSSION

1. Implementation of Official Discretion in the Local Government 
In the Law of State Administration, the legal relationship that exists is between the rulers as the subject of the rule, and the citizens as subjects of the governed. The ruler, in this case, commands, performs bestuurszorg that is to carry out the public interest run by the ruler of state administration, where the ruler has to be have authority ${ }^{3}$.

State Administration Laws of its enforcement may be imposed on the public without exception. This is certainly due to a special authority owned by the institutions or government apparatus. State administration law arrange that, public power can be forced to be realized in the performance of governmental tasks, if they doing mistakes. And furthermore the law of state administration provides forcible attempts to certain situations, such as maladministration ${ }^{4}$. With that authority a government apparatus can make a policy which is can take the form of a decision, both rule (regeling) and decision (beschiking). In policy making, a government apparatus is tied to his or her authority and also bound by several principles that surround of it.Thus all officials in the administration of government have limits to prevent the abuse of authority.

Every official of the state administration in acting (performing their duties) shall be based on legitimate authority, which is given by the laws and regulations. Governance should be based on law (wet matigheid van bestuur = legality principle = le rincile de la egalite de'l administration). Therefore, any state administrative officer prior to carrying out his duties must first be laid with a legitimate authority under the laws and regulations. Thus, the source of government authority is in the legislation.

In general authority, the power to perform all public legal actions can be described to the meaning of government authority such as: ${ }^{5}$

a. Right to run a government affair (in the narrow sense);

b. Right to be able to significantly influence decisions to be taken by other government agencies/ institutions (in the broad sense).

The use of government (public) authority, must follow the rules of state administrative law, there is no misuse of authority. Public authority consists of two extraordinary powers, which have meaning it can not be opposed in the usual way: (Prajudi Admosudirdjo,1988)

a. Prealeable authority, which is the authority to make decisions taken without prior approval from any party.

b. Ex officio authority, an example of authority in the framework of decision-making taken because of his position, so that can not be opposed by anyone (who dare to be opposed, will face a criminal sanction) which is legally binding for the whole of the community.

\footnotetext{
${ }^{3}$ Anna Erliyana, et al, Hukum Administrasi Negara, Edisi Revisi,(Depok: CLGS FHUI, 2007), p. 28

${ }^{4}$ H.W.R Wade and C.F Forsyth, Administrative Law, $7^{\text {th }}$ ed., (New York: Oxford University Press, 1994),

${ }^{5}$ Prajudi Admosudirdjo, Hukum Administrasi Negara, (Jakarta: Ghalia Indonesia, 1988), p.86
} p. 5 
In the implementation of the authority of the government, the administrative officer of the state shall take a decision which basically shall be upon written request, either from an institution or individual person. In making the decision is bound there are three legal principles such as: (Prajudi Admosudirdjo,1988)

a. The principle of jurisdiction (rechmatigeheid), means that any act of state administrative officer shall not violate the law in general (must be in accordance with a sense of justice and decision);

b. Legality principle (wetmatigeheid), an example of every action of state administrative officials should have a legal basis (there are basic rules underlying it). Moreover, Indonesia is a legal state, then the principle of legality is the most important thing in every government action;

c. The principle of discretion (freis ermessen), the freedom of a state administrative official to make decisions based on his own opinion, provided that it does not violate the principle of jurisdiction and the principle of legality mentioned above.

Discretion or Freies Ermessen as a freedom of action would certainly be susceptible to the complexity of the problem because it deviated the principle of legality in the sense of "exceptional". Even when the implementation is misdirected, the policy of this type does not lead to even greater harm to the people. The experience so far shows that many of the government apparatus who issue discretion are not in accordance with the rules that has been determined. ${ }^{6}$

Discretion can only be done by authorized Government Officials. Any use of Government Official Dispute aims to:

a. launching the administration;

b. fill the legal void;

c. provide legal certainty; and

d. overcome the stagnation of government in certain circumstances for the benefit and the public interest.

Government Official's Discretion includes:

a. decision-making and / or action under the provisions of legislation providing a choice of Decisions and / or Actions;

b. decision-making and / or action as the laws and regulations are not regulated;

c. decision-making and / or action due to incomplete or unclear legislation; and

d. decision-making and / or action due to government stagnation for broader interests.

Government officials using Discretion must be eligible:

a. in accordance with the purpose of the Dissertation as referred to Republic of Indonesia Laws, Article 22 paragraph (2) Number 30 of 2014;

b. not contrary to the provisions of laws and regulations;

${ }^{6}$ T.M.Taufik Alamsyah, Efektivitas Penggunaan Diskresi dalam Rangka Mewujudkan Pemerintahan yang Baik, Juristek, Vol. 2, No. 1, Juli 2013, p. 256 
c. in accordance with Good Governance Principle;

d. based on objective reasons;

e. does not constitute Conflict of Interest; and

f. have a good faith.

The use of Discretion which potentially alters the budget allocation shall obtain the approval of the head officers in accordance with the provisions of the laws and regulations. The intended approval is made when the use of discresin poses legal consequences that could potentially burden the state finances. In the case of the use of Discretion causing public unrest, emergency, urgency and / or natural disaster, the Government Official shall notify the head officers before the use of the Discretion and report to the head ffficer's after using the Discretion.

The use of discretion (freis ermessen), tends to be abused, that's why in its use must be for certain reasons such as ${ }^{7}$ : (Bachsan Mustafa,1979)

a. There is an important or justifiable reason for the background of the conduct of state administration;

b. The act still exists within the scope of the task given to it by the laws;

c. The relevant state administrative official may be held accountable for his actions.

However, the use of discretionary authority sometimes causes negative consequences if the use is too excessive and regardless of other principles, the result is:

a. Abuse of power

According to Hood Philips' judge, "abuse of power of implement a power for an authorized purpose, disregarding decision or taking into account irrelevant consideration"8(O.Hood Philis dan Jachsin,2001)

b. Detournament de pouvoir (misuse of authority)

According to Prajudi Atmosudirdjo, the meaning of detournament de pouvoir is when an authority by a state administration official is used for purposes that are contrary to or deviate from what is intended or directed by authority as determined by the law concerned ${ }^{9}$ (Prajudi Admosudirjo,1988). Furthermore, regarding detournament de pouvoir by J.Mainake is defined as "acts committed to achieve a public purpose other than the public purpose referred to by the rules on which the act is based." Prins also provides the observation of detournament de pouvoir, as follows: "if the term detournament de pouvoir will be used to describe a distinctive and extraordinary form of misuse of authority, it is good that the term is used only in the case of state administration using the given to him is to prioritize the common good of others that should be prioritized according to the authority given to him".

\footnotetext{
${ }^{7}$ Bachsan Mustafa, Pokok-Pokok Hukum Administrasi, (Bandung: Alumni, 1979), p. 111-112

${ }^{8}$ O. Hood Philis and Jachson, Constitutional and Administrative Law, (London: Sweet and Maxwell, 2001), p. 701

${ }^{9}$ Prajudi Admosudirdjo, Hukum Administrasi Negara, (Jakarta: Ghalia Indonesia, 1988), p.90-91
} 
c. Ultra vires (misuse of authority)

Hood Philips declared ultra vires as " A decision may fall outside those powers and so be ultra vires because the body concerned has attempted to deal with a matter outside the range of the power conferred on it"10.

In the execution of discretion by government officials, the limits to be considered are the application of general principles of good governance.

The application of discretion such as ${ }^{11}$ :

a. Not contrary to applicable legal system (positive rule of law)

b. Aimed at the public interest.

c. The action is taken to solve the crucial problems.

d. This action can be held morally accountable to God and legally.

e. The principle of morality

f. A sense of justice developed in the midst of society.

Procedure of Use of Discretion, Article 26, Law Number 30 of 2014,

1) Officers using Discretion shall describe the purpose, substance, and impact of administration and finance.

2) Officers using Discretion shall submit a written approval request to the head Officers.

3) Within 5 (five) working days after the application file is received, the head Officers shall issue approval, corrective instruction, or refusal.

4) If the head Officers makes a refusal, the head Officers must provide the reasons for the denial in writing.

The example of discretion in the implementation of local government is filling the position openly or known by the term of office auction. Another example is government officials who do discretion here is the element that performs the functions of government, both within the government and other state organizers. A simple example of clear discretion and can be seen in everyday life is a traffic policeman who controls traffic at a crossroad, which is actually set up by a traffic light. Under the Traffic Act, police can withstand vehicles from one street despite the green light or allow road vehicles despite red lights.

Discretion can also be done by state organizers. The State Organizer pursuant to Article 1 Sub-Article 1, Law Number 28 of 1999 concerning the Implementation of a Clean and Free State of Corruption, Collusion and Nepotism is a state official performing executive, legislative or judicial functions and other officials whose functions and duties relate to the implementation of the state in accordance with the

${ }^{10}$ O. Hood Philis and Jachson, Constitutional and Administrative Law, (London: Sweet and Maxwell, 2001), p. 699

${ }^{1}$ Supandi, Kewenangan Diskresi Pemerintah dalam Sistem Hukum Indonesia, Bunga Rampai Peradilan Administrasi, (Yogyakarta: Genta press, 2014), p.35 
provisions of applicable legislation ${ }^{12}$. One of the organizers referred to here is a judge. For a criminal judge, the discretion implies the attempt of a judge to decide a criminal case to put forward substantive justice. The judge is free to make judgments and decisions, including deviating from the principle of legality, for the purpose of achieving substantive justice.

Furthermore, discretion is formally written, but in its implementation is unwritten, officials also can issue discretion in implementing their authority as long as it can be accounted for. Accountability in discretionary execution and implementation is essential to ensure that no arbitrary action occurs. In the local regions, discretion is also used to facilitate the implementation of development by keeping in mind the general principles of good governance which is concerns with legal certainty, usefulness, impartiality, carefulness, not abuse authority, openness, public interest and good service.

\section{Supervision of Officials' Discretion in the Implementation of Local Government}

Sondang P Siagian provides a definition of supervision that is the process of observation rather than the implementation of all organizational activities to ensure that all work underway is carried out in accordance with predetermined plans ${ }^{13}$. Under the Law of State Administration, the plan is a part of the government's legal action (bestuurrechtshan delling), an act intended to cause legal consequences ${ }^{14}$ (Ridwan HR,2011).

In the framework of the execution of work and to achieve the objectives of the government that has been planned, it is necessary to have supervision because with such supervision as well as objectives to be achieved can be seen with guided plan (planning) which has been established by the government itself. So in principle, supervision is held with a view to: ${ }^{15}$

a. Knowing the course of work, whether succest or not;

b. Fixes errors made by employees and prevents them from recurring the same errors or new errors;

c. Find out whether the budget usage that has been set in the plan is directed to the target and in accordance with the plan;

d. Knowing the implementation of work in accordance with the program (phase of implementation level) as specified in the planning or not;

\footnotetext{
${ }^{12}$ Republic of Indonesia Law Number 28 of 1999 tentang Penyelenggara Negara yang Bersih dan Bebas dari Korupsi, Kolusi, dan Nepotisme

13 S.P. Siagian, Filsafat Administrasi, (Jakarta: Gunung Agung, 1990), p.107, Look at Viktor M. Situmorang. 1998. Aspek Hukum Pengawasan Melekat Dalam Lingkup Aparatur Pemerintah. Jakarta: PT Rineka Cipta. P. 19

${ }^{14}$ Ridwan H.R, Hukum Administrasi Negara. (Jakarta: PT. Raja Grafindo Persada, 2011), p. 187-188

15 Viktor M. Situmorang, Aspek Hukum Pengawasan Melekat dalam Lingkup Aparatur Pemerintah, (Jakarta: PT Rineka Cipta, 1998). Look at Nurfaika Ishak, Pengawasan Penangkapan Ikan di ZEE Indonesia, (Skripsi, Mahasiswa Universitas Hasanuddin, Makassar, 2015), p. 15
} 
e. Knowing the results of work compared with what has been defined in the planning of the standard.

Various kinds of supervision, such as: (Viktor M.Situmorang,1998) ${ }^{16}$

a. Direct Control and Indirect Supervision

Direct supervision is the supervision made personally by the leader or supervisor by observing, examining, reviewing, checking on the spot and receiving reports directly from the executor. This is done by inspection. While indirect supervision is conducted by studying reports received from the executor both oral and written, studying the opinions of the community and so on without supervision "on the post".

b. Preventive and Repressive Supervision

Preventive control is carried out through pre-audit before the work begins. While repressive supervision is done through post audit, with examination of on-site implementation (inspection), requesting implementation report and so on.

c. Internal and External Control

Internal supervision is the supervision conducted by the apparatus within the organization itself. Basically supervision should be done by the head officers itself. However, in practice this is not always possible. Therefore, every unit leader in the organization is basically obliged to assist the top management supervisors functionally in accordance with their respective field of duty. Supervision as an organic function, built-in in every leadership position; they should oversee the special unit that assists and on behalf of the top command supervises the entire apparatus within the organization, such as the inspectorate general within the department. While external supervision is supervision conducted by officials from outside the organization itself.

Legal supervison of government action is a rechtmatigheid supervision, not just from the wetmatigheid only. Legal supervison is an assessment of the legitimacy of a government action that resulted in legal consequences. Such supervision is usually done by judicial law. The system of government of the Unitary State of the Republic of Indonesia according to the 1945 of Indonesian Constitution gives freedom to regions to organize regional autonomy. In the implementation of regional autonomy, it is deemed necessary to put more emphasis on the principles of democracy, community participation, equity and justice, and attention to the potential and diversity of the region. Therefore, the organizer of regional autonomy is to provide broad, real and responsible authority to the regions proportionally ${ }^{17}$ (Diana Halim Koentjoro,2004).

${ }^{16}$ Viktor M. Situmorang, Aspek Hukum Pengawasan Melekat Dalam Lingkup Aparatur Pemerintah, (Jakarta: PT Rineka Cipta, 1998). Look at: Nurfaika Ishak, Pengawasan Penangkapan Ikan di ZEE Indonesia, (Skripsi, Mahasiswa Universitas Hasanuddin, Makassar, 2015), p. 16-17

${ }^{17}$ Diana Halim Koentjoro, Hukum Administrasi Negara, (Bogor: Ghalia Indonesia, 2004), p.30 
The authority of the government based on: ${ }^{18}$

1) Any Decision and / or Actions shall be established and / or performed by the Authorized Institutions and / or Government Official.

2) The Agency and / or Government Officials in the use of Compulsory Authority shall be based on:

a. Laws and Regulations

b. Good Governance Principle

3) Government Administration Officials are prohibited from misusing authority in determining and / or performing Decisions and / or Actions.

Furthermore $^{19}$, Each Decision and / or Action shall be in accordance with the provisions of the laws and regulations and the good governance principle. The laws and regulations shall include: the laws and regulations on which the Authority is based; and laws and regulations which form the basis for establishing and / or conducting Decisions and / or Actions.

The Agency and / or Government Official in determining and / or performing Decisions and / or Measures shall include or indicate the provisions of the laws and regulations on which the Authority is based and the basis for establishing and / or conducting Decisions and / or Actions.

The absence or lack of clarity of legislation as referred to in paragraph (2) letter b shall not preclude the Agency and / or Government Officials authorized to establish and / or perform Decisions and / or Actions insofar as they are of general benefit and in accordance with the good governance principle.

The authority of government officials is obtained from Attribution, Delegation, and/or Mandate. Attribution provide the Government Official shall obtain Authority through: by the 1945 Constitution of the State of the Republic of Indonesia and/or the laws and regulations; is a new or previously non-existent authority; and attribution is given to the institutions and/or Government Officials.

The Agency and/or Government Officials who are authorized through Attribution, the responsibility of the Authority shall be with the Governing Institution and/or the Government Official concerned.

The Authority of Attribution can not be delegated, except as provided for in the 1945 Constitution of the State of the Republic of Indonesia and/or the law. ${ }^{20}$

Delegation, Article 13

1) Delegation of Authority shall be stipulated in accordance with the provisions of laws and regulations.

2) The Agency and / or Government Official shall obtain Authority through the Delegation if:

\footnotetext{
${ }^{18}$ Republic of Indonesia Law, Article 8 Number 30 of 2014 tentang Administrasi Pemerintahan

${ }^{19}$ Republic of Indonesia Law, Article 9 Number 30 of 2014 tentang Administrasi Pemerintahan

${ }^{20}$ Republic of Indonesia Law, Article 12 Number 30 of 2014 tentang Administrasi Pemerintahan
} 
a. provided by the Governing Body / Officials to the Agency and / or other Government Officials;

b. stipulated in a Government Regulation, a Presidential Regulation, and / or a Regional Regulation; and

c. is a delegate or previously existing Authority.

3) Authorities delegated to the Institution and / or Government Officials can not be delegated further, unless otherwise provided by the laws and regulations.

4) In the case where the provisions of other legislative rules specify as referred to in paragraph (3), the Institution and / or Government Official obtaining the Authority through the Delegation as referred to in paragraph (2) may subdue the Action to the Institution and / or other Government Officials with conditions:

a. set forth in the form of a regulation before authority is implemented;

b. done within the government itself; and

c. shall be granted to the Institution and / or Government Officials 1 (one) level below.

5) The Agency and / or Government Official giving the Delegate may use its own Authority which has been granted through the Delegate, unless otherwise provided in the provisions of the laws and regulations.

6) In the case of the implementation of Authority under the Delegation, it shall result in ineffectiveness of the administration, the Governing Institution and / or Government Offering the Delegation of Authority may withdraw the Delegated Authority.

7) The Agency and / or Government Official obtaining Authority through the Delegate, the responsibility of the Authority shall be with the Delegate.

Mandate, Article 14

1) The Institutions and / or Government Official shall obtain a Mandate if:

a. assigned by the Institution and / or Government Officials higher; and

b. it is the implementation of routine duties.

2) Official performing routine duties as referred to in paragraph (1) letter b shall consist of:

a. a daily executive performing the regular duties of a definitive official who is temporarily absent; and

b. executor of duties that perform the regular tasks of definitive officials who are unable to remain.

3) The Governing Body and / or Government may grant the Mandate to the Governing Body and / or other Government Officials who are subordinate, unless otherwise provided in the provisions of the law.

4) The Governing Body and / or Government Officials receiving the Mandate shall state on behalf of the Governing Body and / or Government that grants the Mandate. 
5) The Governing Body and / or Government that grants the Mandate may use its own Authority which has been granted through the Mandate, unless otherwise provided in the provisions of the law.

6) In the event that the exercise of Authority under the Mandate creates ineffectiveness of the administration, the Governing Body and / or Government Officials granting the Mandate may withdraw the mandated Authority.

7) The Governing Body and / or Government Officials who have the Authority through the Mandate are not authorized to make strategic decisions and / or actions that affect the change of legal status on the organizational, personnel, and budgetary aspects.

8) The Governing Body and / or Government Official obtaining Authority through the Mandatory Responsibility Authority Mandate to the Mandate provider.

Furthermore, in the supervision of government officials' discretion that also needs to be considered is the limitation of the authority of the government officials.

Authorities of the Institution and / or Government Officials are limited by: ${ }^{21}$

1) period or grace period of Authority;

2) territory or area of entry into force of Authority; and

3) field coverage or Authority material

That's why, the Institution and / or Government Officials who have terminated or grace periods of Authority shall not be allowed to take Decisions and / or Actions, one of which is discretion.

Then, in the supervision of the discretion of government officials who become the next focus is the prohibit of the misuse of authority. Institution and / or Government Officials are prohibited from misusing authority. Prohibition of abuse of Authority as intended includes:

1) prohibition beyond Authority;

Categorized as exceeding authority if:

a. exceeding the term of office or the period of validity of the Authority;

b. exceeds the territory limits of the entry into force of Authority; and / or

c. contrary to the provisions of legislation.

2) prohibition of confusing Authority; and / or

Categorized as confusing authority if:

a. outside the scope of the area or material of the given authority; and / or

b. contrary to the purpose of the given authority.

3) prohibition of acting arbitrarily.

Categorized as acting arbitrarily if:

a. without base from Authority; and / or

b. is contradictory to a Court Decision with a permanent legal force.

${ }^{21}$ Republic of Indonesia Law, Article 15 Number 30 of 2014 tentang Administrasi Pemerintahan 
Supervision of the prohibition of abuse Authority is carried out by government internal control apparatus ${ }^{22}$. The results of supervision by the government internal supervisors are:

1) there is no error;

2) there are administrative errors; or

3) There is an administrative error that causes the state financial loss.

If the result of supervision of the internal government apparatus there is an administrative error then follow-up in the form of administrative improvement in accordance with the provisions of legislation.

If the result of internal government apparatus supervision is in the form of an administrative error causing the state financial loss, then the state financial loss should be repaid no later than 10 (ten) working days after the decision is made and the result of the supervision is issued. The return of state losses shall be borne by the Governing Body, if the administrative error as intended does not occur because of the element of abuse of Authority. Returns on state losses are imposed on Government Officials, if administrative errors occur due to an element of abuse of Authority.

\section{CONCLUSION}

In every government officials act or decisions when performing their duties should be based on the legitimate authority, which is given by laws and regulations. The governance should be based on law (wet matigheid van bestuur = legality principle = le rincile de la egalite de'l administration). Therefore, every official administrative officer prior to carrying out his duties must be laid with a legitimate authority under the laws and regulations in the first time. Thus, the source of government authority is in the legislation. It is also a good idea to avoid the occurrence of abuse of power, so all of authority from officials must be limited by laws. Supervision of the discretion from the officials government is focus with the ban of authority misused. Institutions and/or officials government are prohibited from misusing their function, task, and authority. Prohibition of abuse of power as mentioned such as: prohibition beyond authority; prohibition of confusing authority; and / or prohibition of acting arbitrarily. Supervision of the prohibition of abuse Authority is carried out by internal government apparatus control. The results of supervision by the internal government apparatus control are: no errors; there are administrative errors; or there are administrative errors with financial loss to the state.

Implementation of the discretion of officials in the government must be concentrate to the existing rules in order to avoid abuse of power or arbitrary act. Discretion which taken by officials government was intended to give benefit to the people, not for certain interests that can cause disadvantageous to the people and the

\footnotetext{
${ }^{22}$ Republic of Indonesia Law, Article 15 (1) Number 30 of 2014 tentang Administrasi Pemerintahan
} 
state. Supervision of discretion from the official government in the administrative should be carried out with professionalism and integrity to prevent collusion, corruption, and nepotism. Supervision becomes very important to keep the system of government implemented properly.

\section{References}

Agus Dwiyanto, dkk, Reformasi Birokrasi Publik di Indonesia, (Yogyakarta: Galang Pritika, 2002)

Anna Erliyana, et al, Hukum Administrasi Negara, Edisi Revisi,(Depok: CLGS FHUI, 2007)

Diana Halim Koentjoro, Hukum Administrasi Negara, (Bogor: Ghalia Indonesia, 2004)

H.W.R Wade and C.F Forsyth, Administrative Law, $7^{\text {th }}$ ed., (New York: Oxford University Press, 1994)

Indroharto, Usaha Memahami Undang-Undang Tentang Peradilan Tata Usaha Negara, (Jakarta: Sinar Harapan, 1993)

Lutfi Effendi, Pokok-Pokok Hukum Administrasi, (Malang: Bayumedia Publishing, 2003)

M. Faal, Diskresi Kepolisian, (Jakarta: PT. Pradnya Paramita, 1991)

Mahfud MD. Lihat dalam Mahmuzar, Sistem Pemerintahan Indonesia menurut UUD 1945 Sebelum dan Sesudah Amandemen, (Bandung: Nusa Media, 2010)

O. Hood Philis and Jachson, Constitutional and Administrative Law, (London: Sweet and Maxwell, 2001)

Philipus Mandiri Hadjon et al, Pengantar Hukum Administrasi Indonesia, (Yogyakarta: Gadjah Mada University Press, 1995)

Poerwasunata, W.J.S, Kamus bahasa Indonesia edisi ketiga,( Jakarta :Balai Pustaka, 2003) Prajudi Admosudirdjo, Hukum Administrasi Negara, (Jakarta: Ghalia Indonesia, 1988) Ridwan H.R, Hukum Administrasi Negara. (Jakarta: PT. Raja Grafindo Persada, 2011) Ridwan HR, Dimensi Hukum Administrasi dan Peradilan Administrasi, (Yogyakarta: FH UII, 2009)

Ridwan HR, Hukum Administrasi Negara, (Yogyakarta: UII Press, 2002)

S.P. Siagian, Filsafat Administrasi, (Jakarta: Gunung Agung, 1990)

SF Marbun, Dimensi-Dimensi Pemikiran Hukum Administrasi Negara, (Yogyakarta: UII Press, 2001)

Soerjono Soekanto, Pokok-Pokok Sosiologi Hukum, (Jakarta: PT. Raja Grafindo Persada, 2006)

Utang Rosidin, Otonomi Daersah dan Desentralisasi, (Bandung: Pustaka Setia, 2015)

Utrecht, E, Pengantar Hukum Administrasi Negara Indonesia, cetakan ke empat, Jakarta,1957 
Victor Situmorang, Dasar-dasar Hukum Administrasi Negara, (Jakarta: Bina Aksara, 1988)

Viktor M. Situmorang, Aspek Hukum Pengawasan Melekat Dalam Lingkup Aparatur Pemerintah, (Jakarta: PT Rineka Cipta, 1998)

\section{Artikel Ilmiah}

Arfan Faiz Muhlizi, Reformulasi Diskresi dalam Penataan Hukum Administrasi, Jurnal Rechtsvinding Vol.1 Nomor 1, April 2012

Azmi Fendri, Kebebasan Bertindak Pemerintah (Diskresi) Sebagai Perwujudan Nilai-Nilai Moral dan Etika, Jurnal Ilmu Hukum Vol.4 Nomor 3, 2014

Julista Mustamu,Diskresi dan Tanggung Jawab Administrasi Pemerintahan, Jurnal Sasi Vol. 17 No. 2 Bulan April-Juni 2011

Nurfaika Ishak, Pengawasan Penangkapan Ikan di ZEE Indonesia, (Skripsi, Mahasiswa Universitas Hasanuddin, Makassar, 2015)

Philipis M. Hadjon, Kriminalisasi Perbuatan Administrasi dalam Pemberantasan Tindak Pidana Korupsi, Makalah dalam Continuing Legal Education BPHN Kementerian Hukum dan HAM, 2009

T.M.Taufik Alamsyah, Efektivitas Penggunaan Diskresi dalam Rangka Mewujudkan Pemerintahan Yang Baik, Juristek, Vol. 2, No. 1, Juli 2013

\section{Peraturan Perundang-undangan:}

Undang-Undang Dasar NRI 1945

Undang-Undang No. 23 Tahun 2014 Tentang Pemerintahan Daerah

Undang-Undang No. 30 Tahun 2014 Tentang Administrasi Pemerintahan 